Tohoku J. exp. Med., 1983, 140, 161-169

\title{
Ecto-5'-Nucleotidase Activities in Lymphocytes and B Lymphoblastoid Cell Lines from Patients with Congenital Agammaglobulinemia
}

\author{
Shingi Nakae, Shigeru Tsuchiya, Hidesada Okumura, \\ Tasuke Konno and Keiya Tada \\ Department of Pediatrics, Tohoku University School of \\ Medicine, Sendai 980
}

\begin{abstract}
Nakae, S., Tsuchiya, S., Okumura, H., Konno, T. and Tada, K. Ecto-5'Nucleotidase Activities in Lymphocytes and $B$ Lymphoblastoid Cell Lines from Patients with Congenital Agammaglobulinemia. Tohoku J. exp. Med., 1983, 140 (2), 161-169 — Ecto-5'-nucleotidase (ecto-5'-NT) activity was measured in Epstein-Barr virus (EBV)-induced B lymphoblastoid cell lines (LCL) derived from bone marrow cells and peripheral lymphocytes of four patients with congenital agammaglobulinemia (CAG). In control subjects there was no appreciable difference in the range of ecto-5'-NT activity between immunoglobulin (Ig)producing B LCL and their peripheral lymphocytes. Though peripheral lymphocytes of the patients showed lower ecto- $5^{\prime}-\mathrm{NT}$ activities than those of control subjects, ecto-5'-NT activities in Ig-producing B LCL from peripheral lymphocytes of the patients fell into the same range as those in B LCL from control subjects. Ecto-5'-NT activities in non-Ig producing precursor B cell lines derived from bone marrow cells of the patients also registered within the range of the enzyme activity of Ig-producing B LCL from control subjects. B LCL from mothers of the patients, who were presumed to be heterozygotes, also had the same range of ecto- $5^{\prime}$-NT activity as the control subjects. These results indicate that ecto-5'-NT does not appear to be involved in the pathogenesis of congenital agammaglobulinemia. - ecto-5' ${ }^{\prime}$-nucleotidase; congenital agammaglobulinemia; Epstein-Barr virus-induced B lymphoblastoid cell lines
\end{abstract}

Reduced ecto-5'-nucleotidase (ecto-5'-NT, E.C. 3.1.3.5) activity in peripheral blood mononuclear cells (PBM) from patients with adult onset hypogammaglobulinemia (Johnson et al. 1977) and congenital agammaglobulinemia (CAG) (Edward et al. 1978; Webster et al. 1978) has recently been demonstrated. These facts indicated the possibility that ecto-5'-NT deficiency might be a third metabolic error of purine metabolism associated with an immunodeficiency. However, an etiologic relationship between ecto- $5^{\prime}-\mathrm{NT}$ and hypogammaglobulinemia has not been established.

The decreased ecto-5'-NT activity is explained by both the lack of circulating B lymphocytes which normally have high ecto- $5^{\prime}-\mathrm{NT}$ activity and a low T cell ecto$5^{\prime}$-NT activity (Thompson et al. 1979; Rowe et al. 1980). Thompson et al. (1980) suggested that the decreased activity was the result of a lack of ecto-5'-NT activity

Received for publication, September 13, 1982. 
in B cells blocked in maturation at an early stage before the acquisition of surface immunoglobulin (sIg) and ecto-5'-NT, and that measurement of ecto-5'-NT activity in newly established lymphoblastoid cell lines (LCL) might provide a means for the identification of heterozygotes for congenital $\mathrm{X}$-linked agammaglobulinemia.

In view of these reports, we measured ecto-5'-NT activities in PBM of CAG patients, in Epstein-Barr virus-induced (EBV) B LCL derived from patient PBM, and in EBV-induced LCL with precursor B cell characteristics derived from patient bone marrow cells.

\section{Materials and Methods}

Patients. Four males with congenital agammaglobulinemia, two females with hypogammaglobulinemia with IgM production, and a male with severe combined immunoefficiency (SCID) with B cells were included in this study. Their clinical and immunological features were described previously (Tsuchiya et al. 1980). The four males with CAG had histories of recurrent bacterial infections in their early infancy and had hypogammaglobulinemia. Surface Ig-bearing cells were virtually absent from peripheral blood of patients M.O., O.S., and K.Ko., but patient S.T. had a few sIg-bearing cells, less than $0.1 \%$ of PBM. The X-linked inheritance was not confirmed. The two females with hypogammaglobulinemia had surface IgM-bearing cells $(2.4$ and $4.5 \%)$ but no surface IgGand IgA-bearing cells. The male with SCID had lymphocytopenia $\left(600 / \mathrm{mm}^{3}\right)$ which contained $1.5 \%$ of E-rosette forming cells and $47.4 \%$ of sIg-bearing cells. His serum Ig levels were $78 \mathrm{mg} / 100 \mathrm{ml}$ for $\mathrm{IgG}, 63 \mathrm{mg} / 100 \mathrm{ml}$ for IgM, and less than $30 \mathrm{mg} / 100 \mathrm{ml}$ for IgA. No lymphocyte responses to phytohemagglutinin (PHA), concanavalin A (Con A), or pokeweed mitogen (PWM) were observed. Skin tests for delayed type hypersensitivity were negative to Candida albicans, streptokinase-streptodornase (SK-SD), purified protein derivative of tuberculin (PPD), and dinitrochlorobenzene (DNCB).

Isolation of lymphocyte subpopulations. Mononuclear cells were separated from fresh heparinized venous blood and fresh heparinized bone marrow aspirates by FicollPaque (Pharmacial Fine Chemicals Inc., Uppsala, Sweden) density gradient centrifugation (Boyum 1968). Monocytes were removed by passing the mononuclear cells through a Sephadex G-10 column (Pharmacia Fine Chemicals Inc., Piscataway, N.J., USA) according to the method of Ly and Mishell (1974). Separation of monocyte-depleted mononuclear cells into E-rosette forming cells and non-E-rosette forming cells was carried out by rosetting with neuraminidase-treated sheep erythrocytes (SRBC) (Weiner et al. 1973).

Characterization of lymphocyte subpopulations. Monocytes were identified by peroxidase stain, $\mathrm{T}$ cells by rosette formation with neuraminidase-treated SRBC, cells with C3b receptors by rosette formation with IgM antibody-human complement coated SRBC (EAChu) (Tachibana and Ishikawa 1973), and surface Ig positive $\left(\mathrm{sIg}^{+}\right) \mathrm{B}$ cells by immunofluorescence with rabbit FITC-conjugated anti-human Ig serum (DAKO-immunoglobulins, Copenhagen, Denmark) after treatment with acid $\mathrm{pH}$ (Kumagai et al. 1975).

PBM preparations from healthy adult subjects contained an average of $14 \pm 6 \%$ monocytes, $68 \pm 6 \% \mathrm{~T}$ cells, and $10 \pm 4 \% \mathrm{sIg}^{+}-\mathrm{B}$ cells; fractions of E-rosette forming cells contained $94 \pm 1 \% \mathrm{~T}$ cells, less than $2 \% \mathrm{sIg}^{+}-\mathrm{B}$ cells, and less than $1 \%$ monocytes; and fractions of non-E-rosette forming cells contained $75 \pm 5 \% \mathrm{sIg}^{+}-\mathrm{B}$ cells, $5 \pm 2 \% \mathrm{~T}$ cells, and less than $2 \%$ monocytes.

With regard to the CAG patients, $\mathrm{PBM}$ preparations contained no sIg+-B cells, $79 \pm 10 \%$ $\mathrm{T}$ cells, and $13 \pm 6 \%$ monocytes; fractions of E-rosette forming cells contained $89 \pm 8 \%$ $\mathrm{T}$ cells, no $\mathrm{sIg}^{+}-\mathrm{B}$ cells, and less than $2 \%$ monocytes; fractions of non-E-rosette forming cells contained no $\mathrm{sIg}^{+}-\mathrm{B}$ cells, $26 \pm 14 \% \mathrm{~T}$ cells, and less than $2 \%$ monocytes.

Establishment of LCL. Following the method of Tsuchiya et al. (1980), LCL were established in suspension culture by infection either of PBM from eleven healthy adults, six patients with primary immunodeficiency diseases (PID), and three mothers of CAG 
patients, or of bone marrow mononuclear cells (BMM) from four CAG patients (M.O., O.S., K.Ko., and S.T.) with EBV.

All LCL derived from PBM possessed sIg, cytoplasmic Ig (cIg), and complement receptors (C3b and $\mathrm{C} 3 \mathrm{~d})$, and $\mathrm{Ig}$ were secreted into culture supernatants when surveyed by immunofluorescence, rosette formation, and inhibition radioimmunoassay, respectively.

On the other hand, the LCL from BMM of CAG patients possessed almost the same characteristics as the precursor B cells reported by Fu et al. (1980) which lacked sIg, cIg, and secretion of Ig. They had EBV associated nuclear antigen (EBNA), complement receptors (C3b and $\mathrm{C} 3 \mathrm{~d}$ ), Fe receptors for $\mathrm{IgM}$, Con $\mathrm{A}$ receptors, and peanut agglutinin (PNA) receptors. Receptors for $\mathrm{SRBC}$ and terminal deoxynucleotidyl transferase (TdT) were not detected in these cells.

LCL were maintained at the density of 4 to $20 \times 10^{5}$ cells/ml in RPMI 1640 supplemented with $20 \%$ fetal calf serum (FCS) and $60 \mu \mathrm{g} / \mathrm{ml}$ kanamycin.

Ecto-5'-NT assay. Ecto-5'-NT was assayed according to the method of Carson et al. with a few modifications (Carson et al. 1979). The prepared lymphocytes or exponentially growing LCL were washed twice in $40 \mathrm{mM}$ N-2-hydroxyethylpiperazine-N'-2-ethanesulfonic acid (HEPES), $\mathrm{pH} 7.4,130 \mathrm{mM} \mathrm{NaCl}$, and $0.4 \%$ bovine serum albumin (BSA) and resuspended in the same buffer at a final density of 3 to $5 \times 10^{5}$ cells $/ \mathrm{ml}$. All assays were performed in duplicate. In each assay the preparation contained (in a final volume of $35 \mu \mathrm{l}): 8.6 \mathrm{mM} \mathrm{MgCl}_{2}, 50 \mathrm{mM}$ Tris- $\mathrm{HCl}, \mathrm{pH} 7.3,240 \mu \mathrm{M}\left(8-{ }^{14} \mathrm{C}\right)$ adenosine monophsphate (AMP, diluted to $6 \mu \mathrm{Ci} / \mu$ mole with carrier AMP, Amersham, Arlington Heights, Ill., USA), and 6 to $10 \times 10^{4}$ cells. In one of the duplicate samples, $\alpha, \beta$-methylene adenosine diphosphate (AOPCP, Sigma Chemical, St. Louis, Mo., USA), a specific inhibitor of ecto-5'$\mathrm{NT}$, was added at $2.85 \mathrm{mM}$. The reaction was carried out for $1 \mathrm{hr}$ at $37^{\circ} \mathrm{C}$ and terminated with $5 \mu \mathrm{l} 8 \mathrm{M} \mathrm{HCOOH}$. The reaction mixtures were centrifuged at $900 \mathrm{rpm}$ for $10 \mathrm{~min}$ and $10 \mu \mathrm{l}$ aliquots of the supernatant were separated by thin layer chromatography on Merck Cellulose plates (Art. 5786, Merck, Darmstadt) with fluorescent indicators in buthanol: methanol: water: ammonia $(60: 20: 20: 1)$. The reaction products (adenosine, inosine, and hypoxanthine) and substrate (AMP) were located with nonradioactive markers by an ultraviolet lamp; the spots were scraped out and quantified by liquid scintillation counting.

\section{Results}

Ecto-5'-NT activities in PBM from PID patients. The enzyme activities in PBM from seven PID patients are shown in Table 1. Four CAG patients had significantly lower ecto- $5^{\prime}$-NT activity than control subjects $(6.1 \pm 1.6$ as compared with $15.7 \pm 5.2 \mathrm{nmoles} / \mathrm{hr} / 10^{6}$ cells, $n=11, p<0.005$ ). The enzyme activities from two patients with hypogammaglobulinemia with $\operatorname{IgM}$ production were 12.1 and 1.3 nmoles $/ \mathrm{hr} / 10^{6}$ cells, respectively. Ecto- $5^{\prime}-\mathrm{NT}$ in a patient with SCID with B cells was as low as those in the CAG patients.

Ecto-5'-NT activities in lymphocyte subpopulations from CAG patients. Ecto$5^{\prime}$-NT activities in unfractionated PBM, E-rosette forming cells, and non-E-rosette forming cells from four CAG patients and seven control subjects are shown in Table 2. In the control subjects, non-E-rosette forming cells had nearly three times higher ecto-5'-NT activity than E-rosette forming cells. The difference between the two preparations was statistically significant $(26.4 \pm 6.2$ as compared with $8.6 \pm 4.2 \mathrm{nmoles} / \mathrm{hr} / 10^{6}$ cells, $p<0.005$ ). Ecto- $5^{\prime}$-NT activities were $2.5 \pm 0.6$ $\mathrm{nmoles} / \mathrm{hr} / 10^{6}$ E-rosette forming cells from patients and $11.3 \pm 4.8 \mathrm{nmoles} / \mathrm{hr} / 10^{6}$ non-E-rosette forming cells. The latter populations contained no sIg-bearing cells and less than $2 \%$ monocytes. Both of them were lower than those from control 
TABLE 1. Ecto-5'-nucleotidase activities in lymphocytes and lymphoblastoid cell lines from patients with primary immunodeficiency diseases

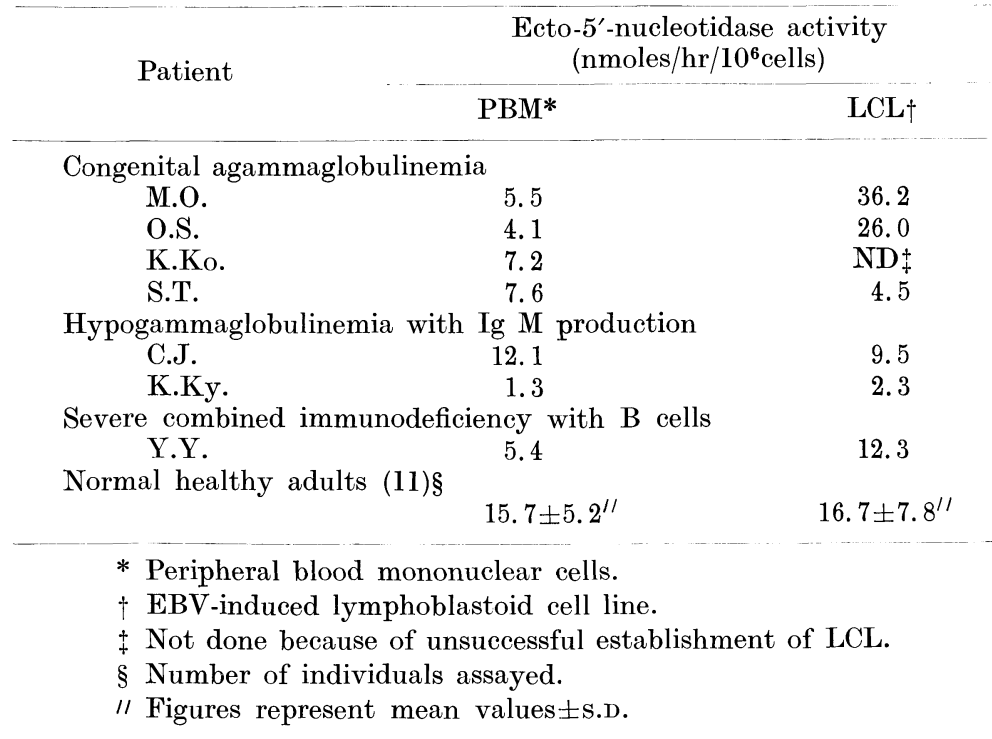

TABLE 2. Ecto-5'-nucleotidase activities in lymphocyte subpopulations from patients with congenital agammaglobulinemia

\begin{tabular}{|c|c|c|}
\hline \multirow{2}{*}{ Lymphocyte subpopulation } & \multicolumn{2}{|c|}{$\begin{array}{l}\text { Ecto- } 5^{\prime} \text {-nucleotidase activity } \\
\left(\text { nmoles } / \mathrm{hr} / 10^{6} \text { cells }\right)\end{array}$} \\
\hline & Control subjects (7) & CAG (4) \\
\hline Unfractionated PBM & $16.7 \pm 5.4$ & $6.1 \pm 1.6$ \\
\hline E-rosette forming cells & $8.6 \pm 4.2$ & $2.5 \pm 0.6$ \\
\hline Non-E-rosette forming cells & $26.4 \pm 6.2$ & $11.3 \pm 4.8$ \\
\hline
\end{tabular}

Figures in parenthesis represent sample numbers.

Figures represent mean values \pm s.D.

The difference in ecto- $5^{\prime}-\mathrm{NT}$ activities in E-rosette and non-E-rosette forming cells from control subjects is statistically significant $(p<0.005$, using Student's $t$-test).

Ecto-5'-NT activities in PBM, E-rosette forming cells, and non-Erosette forming cells of control subjects vs. CAG patients are significantly different $(p<0.005,<0.05$, and $<0.01$, respectively in sequence).

subjects (E-rosette forming cells, $p<0.05$; non-E-rosette forming cells, $p<0.01$ ).

Ecto-5'-NT activities in LCL from PID patients. Newly established LCL were assayed for ecto-5'-NT activity at various intervals during the culture from 40 to 100 days after infection with EBV. The maximum values obtained were defined as enzyme activities for individual LCL. Enzyme assays were performed on the third day after medium replacement when lymphoblasts were growing exponentially and the viability of individual LCL was more than $80 \%$.

As seen in Table 1, ecto-5'-NT activities in LCL from eleven control subjects 
ranged widely and the mean value was $16.7 \pm 7.8 \mathrm{nmoles} / \mathrm{hr} / 10^{6}$ cells. The enzyme activities in LCL from three CAG patients were within the range of the control subjects. In patient K.Ko. with CAG, several attempts failed to establish LCL by infection of PBM with EBV (Tsuchiya et al. 1980). The ecto-5'-NT activities in LCL from patients with hypogammaglobulinemia with IgM production or with SCID were within the range of those of the control subjects. There seemed to be no correlation in ecto-5'-NT activity between PBM and LCL derived from the same patients in any type of PID.

Ecto-5'-NT activities in precursor $B$ cell lines from bone marrow cells of $C A G$ patients. EBV-induced precursor $\mathrm{B}$ cell lines were established from the bone marrow aspirates of four CAG patients (M.O., O.S., K.Ko., and S.T.). Ecto-5'-NT activities of ten precursor $\mathrm{B}$ cell lines (M-1, M-2, M-3, 0-1, 0-3, O-4, K-1, K-2, S-1, and S-2) are shown in Table 3. The enzyme activities in these precursor B cell lines ranged widely. The mean value of $35.5 \pm 20.6 \mathrm{nmoles} / \mathrm{hr} / 10^{6}$ cells was higher than that of B LCL from PBM of control subjects $\left(16.7 \pm 7.8 \mathrm{nmoles} / \mathrm{hr} / 10^{6}\right.$ cells).

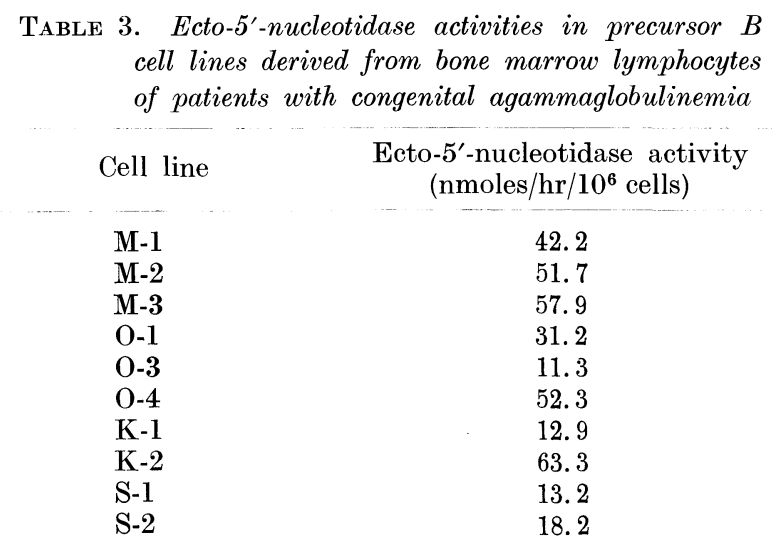

All cell lines assayed here lacked sIg, cIg, and secretion of $\mathrm{Ig}$ into culture supernatants in spite of the presence of EBNA, complement receptors, and Fc receptors for IgM.

Ecto-5'-NT activities in LCL derived from mothers of CAG patients. Ecto-5'-NT activities in LCL varied at each assay. Since the variability appeared to be ascribed to duration of culture, the determination of ecto-5'-NT activities in LCL from eleven control subjects was repeated during culture. As shown in Fig. 1, the initial assays performed soon after the establishment of LCL showed lower ecto- $5{ }^{\prime}-\mathrm{NT}$ activities than the subsequent assays, which inclined to increase in activity until approximately the 70th day of culture and remained at higher levels thereafter.

Ecto-5'-NT activities in LCL derived from three mothers of CAG patients were assayed in a similar way. As shown in Fig. 2, the initial values showed almost the same mean values and the same range of variability between the control subjects 


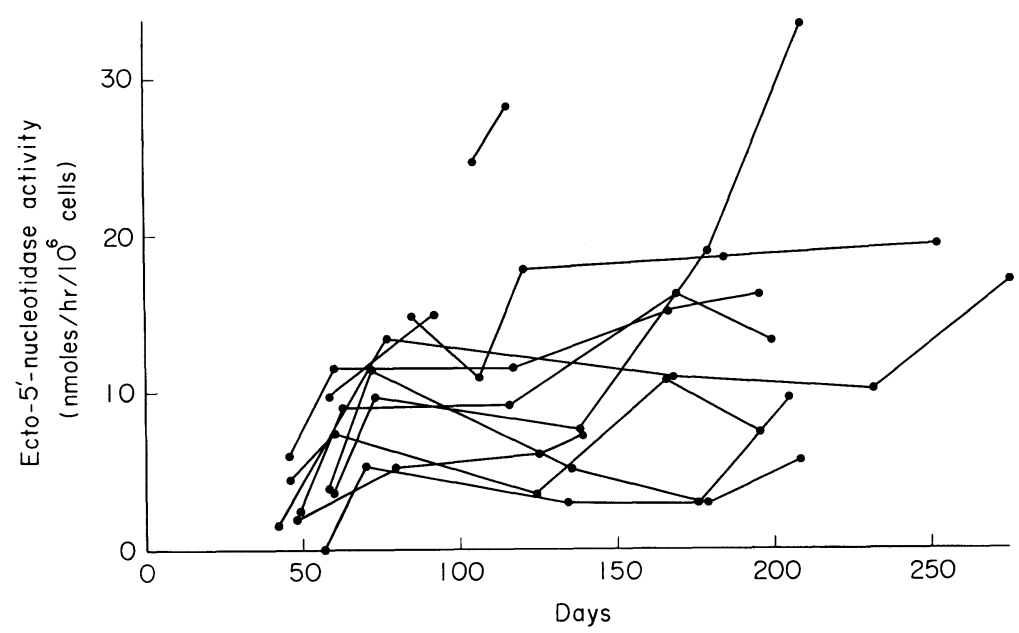

Fig. 1. Ecto-5'-nucleotidase activity in newly established lymphoblastoid cell lines as a function of time in culture. The duration of culture is expressed as the days after infection with EBV.

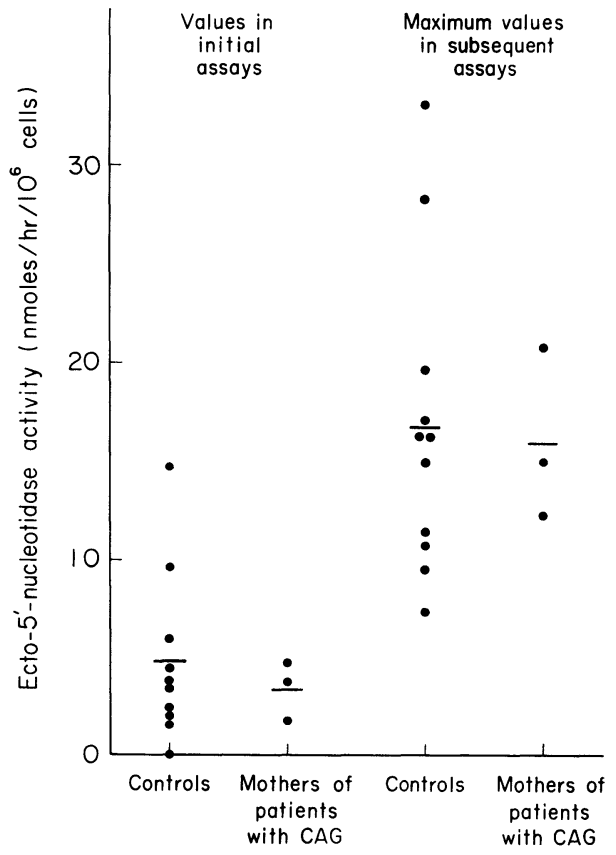

Fig. 2. Ecto- $5^{\prime}$-nucleotidase activities in newly established lymphoblastoid cell lines derived from mothers of patients with congenital agammaglobulinemia at the initial assays and the maximum values in the subsequent assays. Bars in the figure represent the mean values. The mean values $\pm 1 \mathrm{SD}$ are as follows: the values in the initial assays are $4.8 \pm 4.4 \mathrm{nmoles} / \mathrm{hr} / 10^{6}$ cells for eleven control subjects and $3.4 \pm$ $1.5 \mathrm{nmoles} / \mathrm{hr} / 10^{6}$ cells for three mothers of CAG patients; the maximum values in the subsequent assays are $16.7 \pm 7.8 \mathrm{nmoles} / \mathrm{hr} / 10^{6}$ cells for control subjects and $15.9 \pm 4.3$ nmoles $/ \mathrm{hr} / 10^{6}$ cells for mothers.

and the mothers of CAG patients $(4.8 \pm 4.4$ as compared with $3.4 \pm 1.5 \mathrm{nmoles} / \mathrm{hr} /$ $10^{6}$ cells). No difference were observed in the maximum value of ecto- $5^{\prime}-\mathrm{NT}$ activities between LCL from control subjects and the mothers, showing 16.7 \pm 7.8 and $15.9 \pm 4.3 \mathrm{nmoles} / \mathrm{hr} / 10^{6}$ cells, respectively. 


\section{Discussion}

We have previously reported that Ig-producing LCL were established by infection of PBM from CAG patients with EBV (Tsuchiya et al. 1980, 1981). There remained some possibility that the LCL from PBM of the CAG patient were normal LCL which were originated from the few normal B cells with sIg. However, the LCL established from BMM of the patients had unique characteristics concerning Ig production, that is, complete absence of sIg, cIg, and secretion of Ig (Tsuchiya et al. manuscript in preparation). We considered that the established LCL seemed to represent to a considerable extent the characteristics of cells originated at an early stage of B cell maturation. Establishment of these LCL from PBM and BMM of the $\mathrm{CAG}$ patients enabled us to measure ecto- $5^{\prime}-\mathrm{NT}$ activity of $\mathrm{B}$ cell lines from CAG patients themselves, and of B cell lines at early stages of maturation.

Deficiency of ecto-5'-NT in PBM from CAG patients is thought to be due to the scarcity of circulating $\mathrm{B}$ cells which normally have high ecto- $5^{\prime}-\mathrm{NT}$ activity together with a low ecto-5'-NT activity in their T cells (Rowe et al. 1979, 1980; Thompson et al. 1979), or to an increase of immature lymphocytes in the patient's peripheral blood which lack sIg and ecto-5'-NT activity (Rowe et al. 1979; Thompson et al. 1980). B lymphoblasts of chronic lymphocytic leukemia (CLL) have been reported to have low ecto-5'-NT activities (Quagliata et al. 1974; Boss et al. 1979). These CLL cells are thought to originate at an early stage of B cell maturation. Based on these observations, a hypothesis that B lymphocytes acquire ecto-5'-NT during their normal maturation process into plasma cells was proposed (Boss et al. 1979; Thompson et al. 1980).

Low ecto-5'-NT activity was also reported in cord blood B cells (Boss et al. 1980; Rowe et al. 1980) and in B cells from some patients with common variable hypogammaglobulinemia (CVH) (Boss et al. 1980; Edwards et al. 1980). Such low ecto$5^{\prime}$-NT activities, however, were not found consistently in the above-mentioned disease states (Lopes et al. 1973; Silber et al. 1975; Kanter et al. 1979). In the present study ecto-5'-NT activities in both EBV-induced Ig-producing LCL and precursor B cell lines without Ig expression derived from CAG patients were not different from the enzyme activities in B LCL derived from healthy control subjects. From these results, B cells at early stages of maturation are supposed to have similar ecto- $5^{\prime}$-NT activities.

B LCL from mothers of CAG patients who were presumed to be heterozygotes for CAG showed enzyme activities not different from those of control subjects and so heterozygotes for CAG could not be identified by measuring ecto-5'-NT activity in B LCL, as far as our cases were concerned. The results of the present study, however, are not necessarily against the previous assumption that heterozygotes for congenital X-linked agammaglobulinemia could be identified by measuring ecto-5'-NT activity in EBV-induced B LCL, resulting in the low ecto-5'NT activity in them, since the inheritance was unable to be determined in our cases and there remained the possibility of mutation.

In addition, there are reports that an inhibitor of ecto- $5^{\prime}-\mathrm{NT}, \mathrm{AOPCP}$, has no 
effect on the PWM-induced Ig production in vitro (Rowe and Johnson 1979; Edwards et al. 1980), suggesting that lymphocyte ecto-5'-NT is not directly involved in the pathogenesis of hypogammaglobulinemia.

In view of this evidence and our results, it is unlikely that a deficiency of ecto$5^{\prime}-\mathrm{NT}$ is etiologically related to the B cell dysfunction in CAG. It is still unknown why a deficiency of ecto- $5^{\prime}-\mathrm{NT}$ in peripheral lymphocytes is demonstrated in some immunodeficient states including CAG. There remains a possibility that ecto$5^{\prime}$-NT may be related to the function of T cells (Edwards et al. 1979; Rowe et al. 1980; Thompson et al. 1980), having an effect on Ig production. Lower ecto-5'-NT activities shown in rosette forming $\mathrm{T}$ cells from $\mathrm{CAG}$ patients may suggest such a hypothesis.

The findings of the gradual increase and the variability in ecto-5'-NT activity of B LCL during culture may be explained as follows: 1) by the alteration of cell populations with low ecto-5'-NT activity to those with normal ecto-5'-NT activity, that is, $\mathrm{sIg}^{-}$cells may be replaced by $\mathrm{sIg}^{+}$cells during culture (Thompson et al. 1980), and 2) by changes in cell growth, namely, from cells with low ecto- 5 NT activity growing slowly, to cells with high ecto-5'-NT activity growing quickly (Gutensohn 1979). However, B LCL from control subjects and the clones of LCL obtained from tonsillar lymphocytes in semi-solid agar according to the method of Yoshie et al. (1980) showed the changes in ecto-5'-NT activity similar to those observed in B LCL from mothers of CAG patients and no correlation between ecto-5'-NT and cell growth rates was found (unpublished data).

\section{Acknowledgments}

We wish to thank Prof. Nakao Ishida, Department of Bacteriology, Tohoku University School of Medicine, Sendai for his suggestive advice and critical review of the manuscript.

This work was supported in part by a Research Grant from that Intractable Disease Division, Public Health Bureau, Ministry of Health and Welfare, Japan.

\section{References}

1) Boss, G.R., Thompson, L.F., Spiegelberg, H.L., Waldmann, T.A., O'Connor, R.D., Hamburger, R.N. \& Seegmiller, J.E. (1979) Lymphocyte ecto-5'-nucleotidase activity as a marker of B-cell maturation. Trans. Assoc. Amer. Physicians, 92, 309-315.

2) Boyum, A. (1968) Isolation of monuclear cells and granulocytes from human blood. Scand. J. clin. Lab. Invest., 21 (Suppl. 97), 77-89.

3) Carson, D.A., Kaye, J., Matsumoto, S., Seegmiller, J.E., \& Thompson, L. (1979) Biochemical basis for the enhanced toxicity of deoxyribonucleosides toward malignant human $\mathrm{T}$ cell lines. Proc. nat. Acad. Sci. USA, 76, 2430-2433.

4) Edwards, N.L., Maglavy, D.B., Cassidy, J.T. \& Fox, I.H. (1978) Lymphocyte ecto-5'nucleotidase deficiency in agammaglobulinemia. Science, 201, 628-630.

5) Edwards, N.L., Gelfand, E.W., Burk, L., Bosch, H.M. \& Fox, I.H. (1979) Distribution of 5'-nucleotidase in human lymphoid tissues. Proc. nat. Acad.Sci. USA, 76, 3374-3376.

6) Edwards, N.L., Cassidy, J.T. \& Fox, I.H. (1980) Lymphocyte 5'-nucleotidase deficiency in hypogammaglobulinemia: Clinical characteristics. Clin. Immunol. Immunopath., 17, 76-88.

7) Fu, S.M., Hurley, J.N., McCune, J.M., Kunkel, H.G. \& Good, R.A. (1980) Pre-B cells and other possible precursor lymphoid cell lines derived from patients with X-linked agammaglobulinemia. J. exp. Med., 152, 1519-1526. 
8) Gutensohn, W. (1979) Human 5'-nucleotidase. Properties and characterization of the enzyme from placenta, lymphocytes and lymphoblastoid cells in culture. Advanc. exp. Med. Biol., 122B, 295-298.

9) Johnson, S.M., North, M.E., Asherson, G.L., Allsop, J., Watts, R.W.E. \& Webster, A. D.B. (1977) Lymphocyte 5'-nucleotidase deficiency in primary hypogammaglobulinemia. Lancet, 1, 168-170.

10) Kanter, R.J., Freiberger, I.A., Rai, K.R. \& Sawitsky, A. (1979) Lymphocyte populations with $5^{\prime}$-nucleotidase in chronic lymphocytic leukemia. Clin. Immunol. Immunopath., 12, 351-357.

11) Kumagai, K., Abo, T., Sekizawa, T. \& Sasaki, M. (1975) Studies of surface immunoglobulins on human B lymphocytes. I. Dissociation of cell-bound immunoglobulins with acid $\mathrm{pH}$ or $37^{\circ} \mathrm{C}$. J. Immunol., 115, 982-988.

12) Lopes, J., Zucker-Franklin, D., Silber, R. \& Conklin, M. (1973) Heterogeneity of $5^{\prime}$ nucleotidase activity in lymphocytes in chronic lymphocytic leukemia. J. clin. Invest., 52, 1297-1300.

13) Ly, I. \& Mishell, R.I. (1974) Separation of mouse spleen cells by passage through columns of Sephadex G-10. J. Immunol. Methods, 5, 239-247.

14) Quagliata, F., Fraig, D., Conklyn, M. \& Silber, R. (1974) Studies on the lymphocyte $5^{\prime}$-nucleotidase in chronic lymphocytic leukemia, infectious mononucleosis, normal subpopulations, and phytohemagglutinin-stimulated cells. Cancer Res., 34, 3197-3202.

15) Rowe, M. \& Johnson, S.M. (1979) Human lymphocyte ecto-5'-nucleotidase is not directly involved in immunoglobulin production. Biochem. Soc. Trans., 7, 997-998.

16) Rowe, M., De Gast, C.G., Platts-Mills T.A.E., Asherson, G.L., Webster, A.D.B. \& Johnson, S.M. (1979) 5' -nucleotidase of B and T lymphocytes isolated from human peripheral blood. Clin. exp. Immunol., 36, 97-101.

17) Rowe, M., De Gast, C.G., Platts-Mills, T.A.E., Asherson, G.L., Webster, A.D.B. \& Johnson, S.M. (1980) Lymphocyte $5^{\prime}$-nucleotidase in primary hypogammaglobulinemia and cord blood. Clin. exp. Immunol., 39, 337-343.

18) Silber, R., Conklyn, M., Grusky, G. \& Zucker-Franklin, D. (1975) Human lymphocytes: $5^{\prime}$-nucleotidase-positive and negative subpopulations. J. clin. Invest., 56, 1324-1327.

19) Tachibana, R. \& Ishikawa, M. (1973) A new micro-method for quantitation of human T- and B-lymphocytes. Jap. J. exp. Med., 43, 221-230.

20) Thompson, L.F., Boss, G.R., Spiegelberg, H.L., Jansen, I.V., O'Connor, R.D., Waldmann, R.A., Hamburger, R.N. \& Seegmiller, J.E., (1979) Ecto-5'-nucleotidase activity in $\mathrm{T}$ and $\mathrm{B}$ lymphocytes from normal subjects and patients with congenital $\mathrm{X}$ linked agammaglobulinemia. J. Immunol., 123, 2475-2478.

21) Thompson, L.F., Boss, G.R., Spiegelberg, H.L., Bianchino, A. \& Seegmiller, J.E. (1980) Ecto-5'-nucleotidase activity in lymphoblastoid cell lines derived from heterozygotes for congenital X-linked agammaglobulinemia. J. Immunol., 125, 190-193.

22) Tsuchiya, S., Konno, T., Tada, K. \& Ono, Y. (1980) Epstein-Barr virus-induced lymphoblastoid cell lines from patients with primary immunodeficiency diseases. Scand. J. Immunol., 11, 155-162.

23) Tsuchiya, S., Nakae, S., Konno, T., Tada, K. \& Ono, Y. (1981) Estimation of B-cells transformed by Epstein-Barr virus in patients with congenital agammaglobulinemia. Tohoku J. exp. Med., 135, 379-386.

24) Webster, A.D.B., North, M.E., Allsop, J., Asherson, G.L. \& Watts, R.W.E. (1978) Purine metabolism in lymphocytes from patients with primary hypogammaglobulinemia. Clin. exp. Immunol., 31, 456-463.

25) Winer, M.S., Bianco, C. \& Nussenzweig, V. (1973) Enhanced binding of neuraminidase-treated sheep erythrocytes to human T lymphocytes. Blood, 42, 939-946.

26) Yoshie, O., Tada, K. \& Ono, Y. (1980) Immunoglobulin production in Epstein-Barr virus-induced human monoclonal lymphoblastoid cell lines. Tohoku J. exp. Med., 132, $397-403$. 